\title{
Mitochondrial Unfolded Protein Responses in White Adipose Tissue: Lipoatrophy, Whole-Body Metabolism and Lifespan
}

\author{
Masaki Kobayashi $^{1}$ (D), Yuichiro Nezu ${ }^{1}$, Ryoma Tagawa ${ }^{1}$ and Yoshikazu Higami ${ }^{1,2, *(D)}$ \\ 1 Laboratory of Molecular Pathology and Metabolic Disease, Faculty of Pharmaceutical Sciences, \\ Tokyo University of Science, 2641 Yamazaki, Noda, Chiba 278-8510, Japan; kobayashim@rs.tus.ac.jp (M.K.); \\ 3A15073@ed.tus.ac.jp (Y.N.); tagawar@rs.tus.ac.jp (R.T.) \\ 2 Research Institute for Biomedical Sciences, Tokyo University of Science, 2669 Yamazaki, Noda, \\ Chiba 278-8510, Japan \\ * Correspondence: higami@rs.tus.ac.jp; Tel.: +81-4-7121-3676
}

Citation: Kobayashi, M.; Nezu, Y.; Tagawa, R.; Higami, Y. Mitochondrial Unfolded Protein Responses in White Adipose Tissue: Lipoatrophy, Whole-Body Metabolism and Lifespan. Int. J. Mol. Sci. 2021, 22 2854. https://doi.org/10.3390/ ijms22062854

Academic Editor: Takahiko Shimizu

Received: 4 February 2021

Accepted: 8 March 2021

Published: 11 March 2021

Publisher's Note: MDPI stays neutral with regard to jurisdictional claims in published maps and institutional affiliations.

Copyright: (C) 2021 by the authors Licensee MDPI, Basel, Switzerland This article is an open access article distributed under the terms and conditions of the Creative Commons Attribution (CC BY) license (https:// creativecommons.org/licenses/by/ $4.0 /)$

\begin{abstract}
The mitochondrial unfolded protein response (UPR $\left.{ }^{\mathrm{mt}}\right)$ is a stress response mediated by the expression of genes such as chaperones, proteases, and mitokines to maintain mitochondrial proteostasis. Certain genetically modified mice, which defect mitochondrial proteins specifically in adipocytes, developed atrophy of the white adipose tissue, resisted diet-induced obesity, and had altered whole-body metabolism. UPR ${ }^{\mathrm{mt}}$, which has beneficial functions for living organisms, is termed "mitohormesis", but its specific characteristics and detailed regulatory mechanism have not been elucidated to date. In this review, we discuss the function of UPR ${ }^{\mathrm{mt}}$ in adipose atrophy (lipoatrophy), whole-body metabolism, and lifespan based on the concept of mitohormesis.
\end{abstract}

Keywords: mitochondrial unfolded protein response (UPR $\left.{ }^{\mathrm{mt}}\right)$; mitokine; white adipose tissue (WAT); lipoatrophy; mitohormesis

\section{Introduction}

Mitochondria, organelles in eukaryotic cells, originated from specialized aerobic bacteria that were incorporated into the cytoplasm of prokaryotes by endocytosis. The ability of symbiont bacteria to conduct cellular respiration in host cells, which depended on glycolysis and fermentation, would have provided a significant evolutionary advantage. During evolution, DNA of the symbiotic genome was transferred to the nuclear genome of the host cells, but part of it remained as mitochondrial DNA (mtDNA) that replicates autonomously. Mitochondria, which consist of a lipid bilayer membrane containing mtDNA, can replicate and undergo fission and fusion, and unnecessary and/or old damaged mitochondria are removed by autophagy (so-called mitophagy). To maintain mitochondrial quality, host cells have developed various protective systems including the mitochondrial unfolded protein response $\left(\mathrm{UPR}^{\mathrm{mt}}\right)[1-3]$.

mtDNA encodes 13 proteins that partly make up respiratory chain complexes. Most of the approximately 1200 mitochondrial proteins encoded by nuclear DNA possess an $\mathrm{N}$-terminal mitochondrial targeting sequence, are synthesized in the cytoplasm as precursor forms, and are transferred into mitochondria. After the proteins pass through the mitochondrial double-membranes, the mitochondrial targeting sequences of the precursor forms are cleaved by specific mitochondrial signal peptidases (MtSPases). After the cleavage, the proteins mature and acquire their functions. Mitochondria synthesize ATP by oxidative phosphorylation (OXPHOS) via the respiratory chain complex, citric acid cycle, and $\beta$-oxidation. Therefore, mitochondria are called "energy powerplants". Mitochondria also play important roles in various cellular processes including cholesterol synthesis, amino acid metabolism, heat production, calcium storage, and apoptosis [1-3].

White adipose tissue (WAT) is a major tissue for energy storage in the form of triglycerides (TG). Recently, WAT was shown to be an endocrine tissue that secretes adipokines, 
such as adiponectin, leptin, and various inflammatory cytokines. It is well known that the characteristics of adipocytes and their secretory profiles vary with the size of the adipocyte. In general, large adipocytes, usually observed in obese WAT, accumulate more TG in unilocular lipid droplets and secrete less adiponectin and more leptin and inflammatory cytokines, which leads to inflammation, insulin resistance, and leptin resistance. In contrast, small adipocytes secrete more adiponectin and less inflammatory cytokines, are more sensitive to insulin, and function as a powerful buffer for whole-body lipids by absorbing them after feeding and releasing them before feeding [4].

Currently, it is widely accepted that the growth hormone (GH)/insulin-like growth factor 1 (IGF-1)/insulin signaling pathway is the most important regulator of the lifespan and aging processes [5]. In addition, it was reported that WAT itself plays an important role in the regulation of the lifespan. Systemic insulin receptor (IR) knockout (KO) mice die shortly after birth due to ketosis [6]. Similarly, pancreatic $\beta$-cell-specific IR and IGF-1 receptor KO mice die early due to severe diabetes [7]. Myocardial and skeletal muscle-specific $I R$ and IGF-1 receptor $\mathrm{KO}$ mice die from heart failure within a few weeks of birth [8]. In addition, liver-specific IR KO mice developed severe insulin resistance, leading to progressive liver dysfunction [9]. However, in adipose-tissue-specific IR KO mice, the WAT mass was reduced, mitochondrial biogenesis in WAT was enhanced, and their lifespan was extended [10]. Furthermore, transgenic mice, in which the expression of adiponectin was enhanced in the liver, lived longer than controls [11]. CCAAT/enhancer-binding proteins (C/EBPs), sterol regulatory element-binding protein 1 (SREBP1), and peroxisome proliferator-activated receptor $\gamma$ (PPAR $\gamma)$ are critical transcription factors involved in adipocyte differentiation and maturation [4]. Knock-in mice, in which the $C / E B P \alpha$ gene was replaced by the $C / E B P \beta$ gene $(\beta / \beta$ mice), lived longer and showed higher energy expenditure than normal littermates. It was suggested that the beneficial actions of $\beta / \beta$ mice might result from increased WAT energy oxidation and the upregulation of mitochondrial proteins $[12,13]$. In contrast, Ppar $\gamma 2 \mathrm{KO}$ mice, which lack PPAR $\gamma$ exclusively in the WAT, developed severe lipodystrophy, remained insulin-resistant throughout life, and died significantly earlier than controls [14]. We previously reported that SREBP1c is a critical transcription factor in caloric restriction (CR)-induced lifespan extension and metabolic remodeling with enhanced mitochondrial biogenesis in the WAT [15]. Thus, the WAT and its mitochondria are involved in the regulation of whole-body metabolism and lifespan.

Here, we discuss the regulation of whole-body metabolism and lifespan based on the characteristics of WAT, its mitochondria, and UPR ${ }^{\mathrm{mt}}$.

\section{Mitochondrial Unfolded Protein Response}

The UPR ${ }^{\mathrm{mt}}$ is a stress response mediated by the expression of genes that encode chaperones, proteases, and mitokines to maintain mitochondrial proteostasis [1,2]. Mitochondrial chaperones, including mitochondrial heat shock protein 70 ( $\mathrm{mtHSP70/Mortalin/Grp75),}$ HSP60, and HSP10, are involved in protein folding [2,16,17]. Most nuclear-encoded mitochondrial proteins are imported into mitochondria. During this process, the precursor forms of proteins with a mitochondrial targeting signal enter through the translocase complexes of the outer and inner membranes TOM and TIM, respectively [3]. mtHSP70 is localized in the matrix side and is involved in protein transport into the matrix from the intermembrane space [18]. After the precursor form of matrix proteins enters the mitochondria, the targeting sequence is removed by a mitochondrial processing peptidase, followed by the folding of the imported proteins to their active conformation by the molecular chaperones, HSP60 and HSP10. HSP60 and HSP10 form a symmetrical complex and facilitate mitochondrial protein folding, leading to their stability [17]. mtHSP70 also chaperones the imported proteins to prevent their misfolding, aggregation, and mitochondrial protein degradation [19]. HSP60 also interacts with Survivin. The acute ablation of HSP60 by small interfering RNA destabilized Survivin in mitochondria, induced mitochondrial dysfunction, and activated Bax-dependent apoptosis via p53 stabilization by disruption of the HSP60-p53 complex [20]. 
The LON protease (LONP1) and CLPXP complex, major proteases in the mitochondrial matrix, are involved in the degradation of unfolded, damaged, and/or toxic proteins. LONP1 plays an important role in the degradation of oxidized proteins in the mitochondrial matrix, particularly after acute stress [2,21]. Tetradecameric CLpPs form the CLpXP complex with hexameric AAA+ chaperone CLpXs. It was reported that ClpX recognizes unstructured peptide sequences in proteins, proceeds to unfold tertiary structures in the proteins, and then translocates the unfolded polypeptide chain into a sequestered proteolytic compartment in $\mathrm{ClpP}$ for degradation to small peptide fragments [22].

Growth differentiation factor 15 (GDF15; also known as macrophage inhibitory cytokine-1 (MIC-1), nonsteroidal anti-inflammatory drug-activated gene (NAG1)) and fibroblast growth factor 21 (FGF21) are major UPR ${ }^{\mathrm{mt}}$-induced mitokines [1,2]. GDF15 and FGF21 appear to be useful biomarkers in various mitochondrial diseases [23-25]. GDF15, a member of the transforming growth factor-beta superfamily, was originally characterized as a macrophage-derived secretory protein $[26,27]$. It is predominantly expressed in the liver, lung, and kidney in healthy animals [26,28,29], but its expression is also induced in several tissues due to various types of stress [26,30-32]. GDF15 binds to a receptor composed of a heterodimer of Ret and a member of the GDNF receptor $\alpha$ family, known as GFRA-like (GFRAL) in some tissues including the hindbrain [26,33]. However, GDF15, its receptor, and downstream signaling are poorly understood. FGF21, a member of the endocrine FGF superfamily, was initially identified as a hepatokine that regulates lipid and glucose metabolism [34,35]. FGF21, which is mostly secreted from the liver into the bloodstream under fasting conditions, binds to the FGF receptor (FGFR) and beta-klotho (KLB) receptor complex in target tissues, such as the WAT and muscle [36,37]. FGF21FGFR1/KLB signaling is involved in glucose uptake, lipogenesis, and lipolysis [35,36]. Recently, Fgf21 was shown to be expressed in the liver and other tissues, including the WAT, brown adipose tissue, muscle, and pancreas [38]. We recently reported that CR promoted the expression of FGF21 protein expression in the WAT [39].

It is generally accepted that mild-to-moderate UPR ${ }^{\mathrm{mt}}$ is beneficial for living organisms (termed "mitohormesis"), whereas severe UPR ${ }^{\mathrm{mt}}$ can exacerbate disease. Thus, mitohormesis is defined as "biological responses where the induction of an adequate amount of mitochondrial stress leads to an increment in health and viability within a cell, tissue or organism"[40]. However, its true nature and detailed regulatory mechanism, particularly in mammals, have not been elucidated.

\section{Genetically Modified Mice Live Longer Due to a Deficiency of Mitochondrial Proteins or Overexpression of Mitokines}

It was reported that mice with genetic defects in mitochondrial proteins including CLK1/MCLK1/COQ7 and SURF1 lived longer than wild mice [41,42]. CLK-1/MCLK1/COQ7 is a mitochondrial hydroxylase involved in ubiquinone (UQ) biosynthesis [43]. Homozygous Mclk1 KO mice are embryonic lethal, but systemic heterozygous Mclk1 KO mice are born normally and live longer than controls [41]. In homozygous Mclk1 KO mice, low ATP levels, high mitochondrial oxidative stress, and low non-mitochondrial oxidative damage were found [43]. Moreover, the mice were associated with the metabolic alteration of mitochondria and were protected against bacterial infection and subsequent tissue damage [44]. $\operatorname{Coq}^{\mathrm{Q} 95 \mathrm{X}}$ mice, which also have defects in UQ biosynthesis, lived longer than controls and had undetectable levels of COQ9 protein with a moderate UQ deficiency in the brain, kidneys, and skeletal muscle [45]. The hepatic UQ levels were not decreased, and mitochondrial dysfunction and increased oxidative stress did not develop in the liver, suggesting tissue-specific differences in UQ biosynthesis. Therefore, the effect of reduced levels of proteins involved in UQ biosynthesis on increased survival of mice may be due to mitochondrial mechanisms in non-liver tissues or other unknown mechanisms [46]. Moreover, another study reported that CLK-1 localized in the nucleus increased the expression of genes involved in mitochondrial reactive oxygen species (ROS) metabolism, leading to a reduction in ROS. In addition, nuclear CLK-1 suppresses UPR ${ }^{\mathrm{mt}}$. Reduced ROS levels led to the trafficking of CLK from the nucleus and its predominant localization 
in mitochondria. This study suggested that nuclear or mitochondrial CLK-1 functions as a rheostat to maintain ROS homeostasis and attenuate UPR ${ }^{\mathrm{mt}}$ [47]. Thus, the molecular mechanisms involved in lifespan extension related to defects of CLK-1 require further study (Table 1).

SURF1 is an assembly protein for complex IV (cytochrome c oxidase; COX) in the electron transport chain. Patients with a mutation of the Surf1 gene suffer defects of COX activity in multiple tissues, resulting in fatal mitochondrial encephalomyelopathy, termed Leigh syndrome. In contrast, mice lacking the SURF1 protein (Surf1 KO mice) are viable and have a $>50 \%$ reduction in COX activity, resistance to $\mathrm{Ca}^{2+}$-dependent neurodegeneration, and extended longevity [42]. Surf1 KO mice also had a lower body and fat mass, in association with reduced lipid storage, smaller adipocytes, and elevated fatty acid oxidation in the WAT compared with control mice. The respiratory quotient in Surf1 KO mice was significantly lower than that in control animals, and elevated fat utilization was associated with enhanced glucose metabolism. The expression of peroxisome proliferator-activated receptor $\gamma$-coactivator $1-\alpha$ (PGC-1 $\alpha$ ) and its target genes was upregulated in the WAT, heart, and skeletal muscle of Surf1 KO mice [48]. Despite the significant reduction in COX activity, there was little or no difference in ROS generation, membrane potential, ATP production, or respiration in isolated mitochondria from the heart and skeletal muscle of Surf1 KO mice compared with control mice. In addition, the UPR ${ }^{\mathrm{mt}}$-associated proteins, HSP60, ClpP, and LONP1 were elevated in skeletal muscle but not in the heart of Surf1 KO mice compared with control mice, suggesting a tissue-specific effect of UPR ${ }^{\mathrm{mt}}$ in response to SURF1 deficiency $[49,50]$. Taken together, these findings suggest that SURF1 deficiency promotes fat utilization, enhances insulin sensitivity, activates mitochondrial biogenesis in various tissues, induces UPR ${ }^{\mathrm{mt}}$ in the heart and skeletal muscle, and extends longevity (Table 1).

Mitokines, including GDF15 and FGF21, are also involved in whole-body metabolism and/or lifespan [2]. Fgf21 transgenic (Tg) mice, in which the Fgf21 transgene is selectively expressed in hepatocytes under the control of the ApoE promoter, live markedly longer than controls without reducing food intake. Fof21 Tg mice had 5-10 times higher circulating concentrations of FGF21 than controls. Younger Fgf21 Tg mice had significantly decreased insulin, IGF-1, glucose, TG, and cholesterol levels in the serum and TG levels in the liver. These findings based on hepatic transcriptomic analysis suggest that the significant extension of lifespan in F $g f 21 \mathrm{Tg}$ mice might be a result of blunting the GH/IGF-1 signaling pathway in the liver rather than affecting $\mathrm{NAD}^{+}$metabolism, AMP kinase, or mTOR signaling [51].

Female Gdf15 Tg mice had a smaller body size and lived markedly longer than controls. Furthermore, Gdf15 Tg mice had increased serum GH levels but decreased levels of serum IGF-1, insulin, and leptin. Insulin sensitivity and energy expenditure were increased with higher lipid mobilization [52]. In male Gdf15 Tg mice, thermogenesis and oxidative metabolism were increased, glucose tolerance was improved [53], and inflammation was inhibited [54]. Macrophage-specific Crif1 KO mice developed insulin resistance with M1 macrophage-like polarization, but GDF15 treatment upregulated the oxidative function of macrophages, leading to their polarization to an M2-like phenotype, which reversed insulin resistance in Crif1 KO mice fed an HFD, suggesting GDF15 improved glucose metabolism with altered macrophage polarization in the WAT [55]. Taken together, GDF15 suppresses insulin/IGF-1 signaling and inflammation with polarization to an M2 macrophage-like phenotype and enhances energy expenditure with the activation of lipid mobilization and thermogenesis, leading to lifespan extension and suppression of age-related pathologies.

\section{Genetically Modified Mice Have Defective Mitochondrial Protein, Leading to Lipoatrophy, Which Regulates Whole-Body Metabolism}

Mitochondria transcription factor A (TFAM) is important for the stability of mtDNA and initiation of the transcription of genes encoding mtDNA [56]. Adipoq-Tfam KO mice, generated by mating with Adiponectin-Cre mice, developed lipoatrophy and had reduced mitochondrial biogenesis and deterioration of glucose metabolism and heart function and increased inflammation in the WAT and fatty liver [57]. However, adipose-specific 
Tfam-deficient (aP2-Tfam KO) mice, generated by mating with aP2-Cre mice, developed lipoatrophy and reduced mitochondrial biogenesis but had resistance to diet-induced obesity (DIO), as well as improved glucose metabolism and fatty liver and increased energy expenditure [58]. Unfortunately, markers involved in $\mathrm{UPR}^{\mathrm{mt}}$ have not been investigated in Adipoq-Tfam KO mice or aP2-Tfam KO (Table 1).

CR6-interacting factor 1 (CRIF1), also known as CR6/GADD45-interacting protein, is an essential protein for the intramitochondrial translation of mtDNA-encoded oxidative phosphorylation (OXPHOS) subunits [59]. Therefore, CRIF1 deficiency reduced OXPHOS activity. Fat-specific Crif1 deficient (Adipoq-Crif1 KO) mice, generated by mating with Adiponectin-Cre mice, developed lipoatrophy, but whole-body metabolism was not altered when fed a normal diet (ND). In Adipoq-Crif1 KO mice, glucose metabolism was improved, and energy expenditure was increased under the conditions of a high-fat diet (HFD). Moreover, the expression levels of proteins involved in mitochondrial chaperones and proteases, and mRNAs of mitokines, Gdf15 and Fgf21, were upregulated in the WAT of Adipoq-Crif1 KO mice fed ND and HFD. The deletion of either Gdf15 or Fgf21 partly canceled the beneficial effects observed in Adipoq-Crif1 KO mice. Thus, the characteristics seen in Adipoq-Crif1 KO mice might be related to UPR ${ }^{\mathrm{mt}}$-induced GDF15 and/or FGF21 expressions [60] (Table 1).

As described above, ClpP, a component of caseinolytic peptidase (ClpXP), is a proteolytic compartment for the degradation of proteins into small peptide fragments as mentioned above [2,22]. ClpP KO mice showed reduced adiposity, improved insulin sensitivity, and resistance to DIO. Mitochondrial biogenesis was enhanced selectively in the WAT but not brown adipose tissue (BAT), heart, or skeletal muscle of mice fed ND and HFD. UPR ${ }^{\mathrm{mt}}$ markers, including LONP1 and mitochondrial chaperones including HSP60, HSP40, HSP10, and ClpX, were upregulated in the WAT of KO mice fed ND. Moreover, $\mathrm{KO}$ mice were protected from glucose intolerance, insulin resistance, hepatic steatosis, and increased energy expenditure. Thus, the beneficial effects appeared to be increased for mice fed an HFD [61] (Table 1).

Mitochondrial intermediate peptidase (MIPEP), an MtSPase in the mitochondria matrix, cleaves eight amino acids from the $\mathrm{N}$-terminal via mitochondrial processing peptidase (MPP). Thus, Mipep contributes to the second of two successive cleavages, resulting in the maturation of substrate proteins [3]. We previously reported that Sirtuin 3 (SIRT3), cytochrome c oxidase subunit 4 (COX4), and malate dehydrogenase 2 (MDH2) are substrates for MIPEP in the WAT of mice [62]. However, little is known about MIPEP functions, including its substrate in WAT. To investigate the functions of MIPEP, we generated fat-specific Mipep-deficient (Adipoq-Mipep KO) mice, generated by mating with Adiponectin-Cre mice. Adipoq-Mipep KO developed severe lipoatrophy and were resistant to DIO, but wholebody metabolism was not significantly exacerbated under the conditions of feeding with ND and HFD. In the WAT of Adipoq-Mipep KO mice, GDF15 and FGF21 were upregulated, but factors involved in mitochondrial chaperones and proteases were not, suggesting the characteristics seen in Adipoq-Mipep KO mice are not typical of $\mathrm{UPR}^{\mathrm{mt}}$ but are rather an inducible mitokine response (unpublished data, Table 1).

In the BAT of all five genetically modified lipoatrophic mice, which have defective mitochondrial proteins as described in Table 1, reduced size and/or WAT-like phenotypes, including the decreased expression of brown adipocyte markers such as uncoupling protein 1 , were found. These findings suggest that enhanced energy expenditure does not occur in the BAT of these lipoatrophic mice [57-61]. 
Table 1. Genetically modified mice, which show lipoatrohy due to the defect of proteins involved in mitochondria function.

\begin{tabular}{|c|c|c|c|c|c|c|c|c|c|}
\hline Mice Genotype & $\begin{array}{l}\text { Function of } \\
\text { Target Protein }\end{array}$ & $\begin{array}{l}\text { Body } \\
\text { Weigh }\end{array}$ & $\begin{array}{l}\text { Alteration of } \\
\text { WAT and } \\
\text { Adipocytes }\end{array}$ & $\begin{array}{l}\text { Alteration Of Mitochondria } \\
\text { Function }\end{array}$ & $\begin{array}{l}\text { Glucose } \\
\text { Metabolism }\end{array}$ & $\mathrm{Upr}^{\mathrm{mt}}$ & $\begin{array}{l}\text { Adipocyte } \\
\text { Differ. }\end{array}$ & Others & Reference \\
\hline \multicolumn{10}{|c|}{ Genetically modified mice, which live longer due to deficiency of mitochondrial proteins } \\
\hline $\begin{array}{l}\text { Heterozygous } \\
\text { Mclk1 KO }\end{array}$ & $\begin{array}{l}\text { Ubiquinone } \\
\text { biosynthesis }\end{array}$ & $\rightarrow$ & n.r. & $\begin{array}{l}\text { Complex II activity in ES cells } \downarrow \\
\text { Complex II, Complex I-III, Complex } \\
\text { II-III activity in liver } \rightarrow\end{array}$ & n.r. & n.r. & n.r. & $\begin{array}{l}\text { - Resistant to oxidative } \\
\text { stress and infection } \\
\text { - Enhanced immune } \\
\text { response }\end{array}$ & {$[41,43,44]$} \\
\hline $\operatorname{Coq} \mathrm{Q}^{95 \mathrm{X}}$ & $\begin{array}{l}\text { Ubiquinone } \\
\text { biosynthesis }\end{array}$ & $\downarrow$ & n.r. & $\begin{array}{l}\text { Proteins involved in ubiquinone } \\
\text { biosynthesis in brain, heart, kidney } \\
\text { and SKM } \downarrow \text {, in liver } \rightarrow \\
\text { Complex I-III, Complex II-III activity } \\
\text { in female kidney, SKM } \downarrow \text {, in brain } \rightarrow\end{array}$ & n.r. & $\begin{array}{l}\text { Factors involved } \\
\text { in chaperone } \\
\text { and protease in } \\
\text { liver } \rightarrow\end{array}$ & n.r. & $\begin{array}{l}\cdot \text { oxidative stress } \rightarrow \\
\cdot \text { Voluntary running } \\
\text { distance } \downarrow\end{array}$ & {$[45,46]$} \\
\hline Surf1 KO & $\begin{array}{l}\text { Complex IV } \\
\text { assembly }\end{array}$ & $\downarrow$ & $\begin{array}{l}\text { WAT weight: } \downarrow \\
\text { Adipocyte size: } \downarrow\end{array}$ & $\begin{array}{l}\text { Complex IV activity in liver, heart, } \\
\text { SKM and WAT } \downarrow \\
\text { Complex I, II, III activity in heart, } \\
\text { SKM } \rightarrow \\
\text { Mitochondria biogenesis in WAT } \uparrow \\
\text { Amount of Complex II, V in WAT } \uparrow\end{array}$ & Improved & $\begin{array}{l}\text { Factors involved } \\
\text { in chaperone } \\
\text { and protease in } \\
\text { liver, heart } \\
\text { and/or SKM } \uparrow\end{array}$ & $\uparrow / \rightarrow$ & $\begin{array}{l}\cdot \text { Plasma insulin } \downarrow \\
\text { - Resistant to } \mathrm{Ca}^{2+}- \\
\text { dependent } \\
\text { neurodegeneration }\end{array}$ & {$[42,48-50]$} \\
\hline \multicolumn{10}{|c|}{ Genetically modified mice, which defect mitochondrial protein, induce lipoatrophy } \\
\hline $\begin{array}{l}\text { Tfam KO } \\
\text { (aP2-Cre) }\end{array}$ & $\begin{array}{l}\text { Stabilization } \\
\text { and } \\
\text { transcription of } \\
\text { mtDNA }\end{array}$ & $\downarrow$ & $\begin{array}{l}\text { WAT weight: } \downarrow \\
\text { Adipocyte size: } \downarrow\end{array}$ & $\begin{array}{l}\text { mtDNA derived factors in WAT } \downarrow \\
\text { CS in WAT } \uparrow \\
\text { Complex I, IV activity in WAT } \downarrow\end{array}$ & $\begin{array}{l}\text { ND: improved } \\
\text { HFD: improved }\end{array}$ & n.r. & n.r. & • Plasma insulin $\downarrow$ & {$[58]$} \\
\hline $\begin{array}{l}\text { Tfam KO } \\
\text { (Adipoq-Cre) }\end{array}$ & $\begin{array}{l}\text { Stabilization } \\
\text { and } \\
\text { transcription of } \\
\text { mtDNA }\end{array}$ & $\downarrow$ & $\begin{array}{l}\text { WAT weight: } \downarrow \\
\text { Adipocyte size: } \rightarrow\end{array}$ & $\begin{array}{l}\text { Factors encoded mtDNA in WAT } \downarrow \\
\text { CS activity in WAT } \uparrow \\
\text { OXPHOS subunits encoded nuclear } \\
\text { DNA in WAT } \downarrow \\
\text { Complex I, II-III, IV activity in WAT } \downarrow\end{array}$ & $\begin{array}{l}\text { ND: worsen } \\
\text { HFD: worsen }\end{array}$ & n.r. & n.r. & $\begin{array}{l}\text { - Fatty liver } \\
\text { - Inflammation } \\
\text { - Hypertension } \\
\text { - Cardiac dysfunction } \\
\text { - Plasma insulin } \uparrow\end{array}$ & [57] \\
\hline $\begin{array}{l}\text { Crif1 KO } \\
\text { (Adipoq-Cre) }\end{array}$ & $\begin{array}{l}\text { Translation in } \\
\text { mitochondria }\end{array}$ & $\downarrow$ & $\begin{array}{l}\text { WAT weight: } \downarrow \\
\text { Adipocyte size: } \downarrow\end{array}$ & OXPHOS formation in WAT $\downarrow$ & $\begin{array}{l}\text { ND: } \rightarrow \\
\text { HFD: improved }\end{array}$ & $\begin{array}{l}\text { GDF15, FGF21 } \uparrow \\
\text { Factors involved } \\
\text { in chaperone } \\
\text { and protease } \uparrow\end{array}$ & $\rightarrow$ & $\begin{array}{l}\text { - Macrophagein WAT } \\
\text { (predominantly M2) } \uparrow \\
\text { - Fatty liver } \downarrow\end{array}$ & {$[60]$} \\
\hline $\begin{array}{l}\text { Clpp KO } \\
\text { (Cag-Cre) }\end{array}$ & $\begin{array}{l}\text { Mitochondrial } \\
\text { protease }\end{array}$ & $\downarrow$ & $\begin{array}{l}\text { WAT weight: } \downarrow \\
\text { Adipocyte size: } \downarrow\end{array}$ & $\begin{array}{l}\text { Mitochondria biogenesis in WAT } \uparrow \\
\text { ßoxidation in WAT } \downarrow \\
\text { OXPHOS Complex II in WAT } \uparrow\end{array}$ & $\begin{array}{l}\text { ND: improved } \\
\text { HFD: markedly } \\
\text { improved }\end{array}$ & $\begin{array}{l}\text { Factors involved } \\
\text { in chaperone } \\
\text { and protease } \uparrow\end{array}$ & $\rightarrow$ & $\begin{array}{l}\text { - Plasma insulin } \downarrow \\
\text { - Thermogenesis } \uparrow\end{array}$ & [61] \\
\hline $\begin{array}{l}\text { Mipep } \mathrm{KO} \\
\text { (Adipoq-Cre) }\end{array}$ & $\begin{array}{l}\text { Mitochondrial } \\
\text { signal peptidase }\end{array}$ & $\downarrow$ & $\begin{array}{l}\text { WAT weight: } \downarrow \\
\text { Adipocyte size: } \rightarrow\end{array}$ & $\begin{array}{l}\text { Proteins encoded nuclear DNA } \\
\text { (COX4, SIRT3) in WAT } \downarrow \\
\text { Proteins encoded nuclear DNA } \\
\text { (MDH2) in WAT } \uparrow \\
\text { CS activity in WAT } \rightarrow\end{array}$ & $\begin{array}{l}\text { ND: worsen } \\
\text { HFD: slightly } \\
\text { worsen }\end{array}$ & $\begin{array}{l}\text { GDF15, FGF21 } \uparrow \\
\text { Factors involved } \\
\text { in chaperone } \\
\text { and protease } \downarrow\end{array}$ & $\downarrow$ & · Plasma insulin $\uparrow$ & unpublished \\
\hline
\end{tabular}

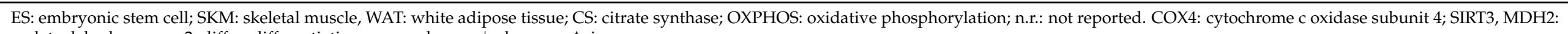
malate dehydrogenase 2; differ: differentiation; $\rightarrow$ : no change; $\downarrow$ : decrease; $\uparrow$ : increase. 


\section{Discussion: Lessons Learned from Genetically Modified Mice that Develop Lipoatrophy Due to Defective Proteins Involved in Mitochondrial Function}

Genetic (inherited, congenital) and acquired lipoatrophy in humans, which can be localized or generalized in distribution, is a heterogenous syndrome. Despite its pathogenesis and different distributions, it is often associated with various metabolic disorders and tissue damage, including insulin resistance, dyslipidemia, and ectopic lipid accumulation such as fatty liver. In these cases, it is termed lipodystrophy. The pathogenesis of human lipodystrophy can be roughly characterized as defective adipocyte differentiation, mitochondrial dysfunction including antiretroviral treatment, dysregulation of lipid metabolism, defective DNA damage repair, or abnormal LMNA genes, including the model for Hutchinson-Gilford Progeria Syndrome, termed "laminopathy" [63]. Thus, mitochondrial dysfunction is one pathogenic form of lipodystrophy.

PPAR $\gamma$ is a master regulator of adipocyte differentiation [4]. Adipose-specific Ppar $\gamma$ deficient (aP2-Ppar $\mathrm{KO}$ ) mice, generated by mating with aP2-Cre mice, developed lipoatrophy with suppressed adipocyte differentiation and fatty liver. Glucose metabolism was not changed under the conditions of ND feeding. Even in aP2-Ppar $\gamma$ KO fed an HFD, glucose metabolism was slightly exacerbated with an approximately two-fold increase in plasma insulin levels [64]. A different adipose-specific Ppar $\gamma$-deficient (Adipoq-Ppar $\gamma$ $\mathrm{KO}$ ) mouse, generated by mating with Adiponectin-Cre mice, developed lipoatrophy with suppressed adipocyte differentiation. Glucose metabolism was markedly exacerbated with a $>100$-fold increase in serum insulin levels. In addition, significant inflammatory cell infiltration and fibrosis were observed in the WAT [65]. In general, serum or plasma insulin levels are elevated relative to the severity of glucose intolerance. Glucose metabolism in Adipoq-Ppary KO mice was markedly exacerbated compared with that in aP2-Ppary $\mathrm{KO}$ mice. Taken together, it is likely that glucose metabolism exacerbated in genetically modified lipoatrophic mice resulting from a deficiency of TFAM or PPAR $\gamma$ is more likely to occur on a background of Adiponectin-Cre than aP2-Cre. Moreover, $a P 2$ is a highly expressed gene in adipocytes but is also expressed in other tissues and cells including macrophages [66]. Indeed, Cre-recombinase activity was present in various tissues in aP2-Cre mice [67]. According to these findings, it is widely accepted that Cre-recombinase activity is more significant and specific in adipocytes from Adiponectin-Cre mice than from aP2-Cre mice. Therefore, mitochondrial stress in WAT is more severe in $\mathrm{KO}$ mice in an Adiponectin-Cre background than in aP2-Cre background.

Recently, it was reported that the inhibition of mitochondrial translation led to the coordinated suppression of cytosolic translation, which might be targeted to promote lifespan [68]. Therefore, we should examine the mito-cytosolic translational balance to understand the pathologies involved in UPR ${ }^{\mathrm{mt}}$. From the viewpoint of glucose tolerance and $\mathrm{UPR}^{\mathrm{mt}}$ based on the findings described in this review, we would like to propose "mitohormesis" in lipoatrophic models (Figure 1). The various severities of mitochondrial stress resulting from defective proteins involved in mitochondrial function induce varying degrees of UPR ${ }^{\mathrm{mt}}$. In cases of mild mitochondrial stress such as that in Adipoq-Crif1 KO mice [60], in Cag-Clpp KO mice [61], and in aP2-Tfam $\mathrm{KO}$ mice [58], UPR ${ }^{\mathrm{mt}}$, including chaperones, proteases, and mitokines, might be fully induced, probably improving wholebody metabolism including glucose tolerance. Such mild UPR ${ }^{\mathrm{mt}}$ might extend the lifespan. To the best of our knowledge, UPR ${ }^{\mathrm{mt}}$ has not been evaluated in Clk1 KO mice, which have high mitochondrial oxidative stress, low non-mitochondrial oxidative damage, and a long lifespan; however, it was reported that mild UPR ${ }^{\mathrm{mt}}$ was induced in Surf1 KO mice, which also have a long lifespan [41,42]. Therefore, the mitochondrial oxidative stress might also induce UPR ${ }^{\mathrm{mt}}$. GDF15 and FGF21 are representative mitokines induced by UPR ${ }^{\mathrm{mt}}$. As mentioned above, $F g f 21 \mathrm{Tg}$ and $G d f 15 \mathrm{Tg}$ mice have extended lifespans [51,52]. In the case of our Adipoq-Mipep KO mice, the expressions of mitokines were induced, but those of mitochondrial chaperones and proteases were not. Therefore, it is likely that $\mathrm{UPR}^{\mathrm{mt}}$ is not fully induced in these mice or that UPR ${ }^{\mathrm{mt}}$-induced beneficial actions are canceled by deteriorated mitochondrial functions. Unfortunately, UPR ${ }^{\mathrm{mt}}$ has not been investigated in 
cases of severe mitochondrial stress such as that in Adipoq-Tfam KO or Adipoq-Ppary KO mice. However, UPR ${ }^{\mathrm{mt}}$ might be not induced, or severe mitochondrial stress might surpass the beneficial actions of UPR ${ }^{\mathrm{mt}}$, leading to accelerated glucose intolerance, ectopic lipid accumulation, and inflammation (Figure 1).

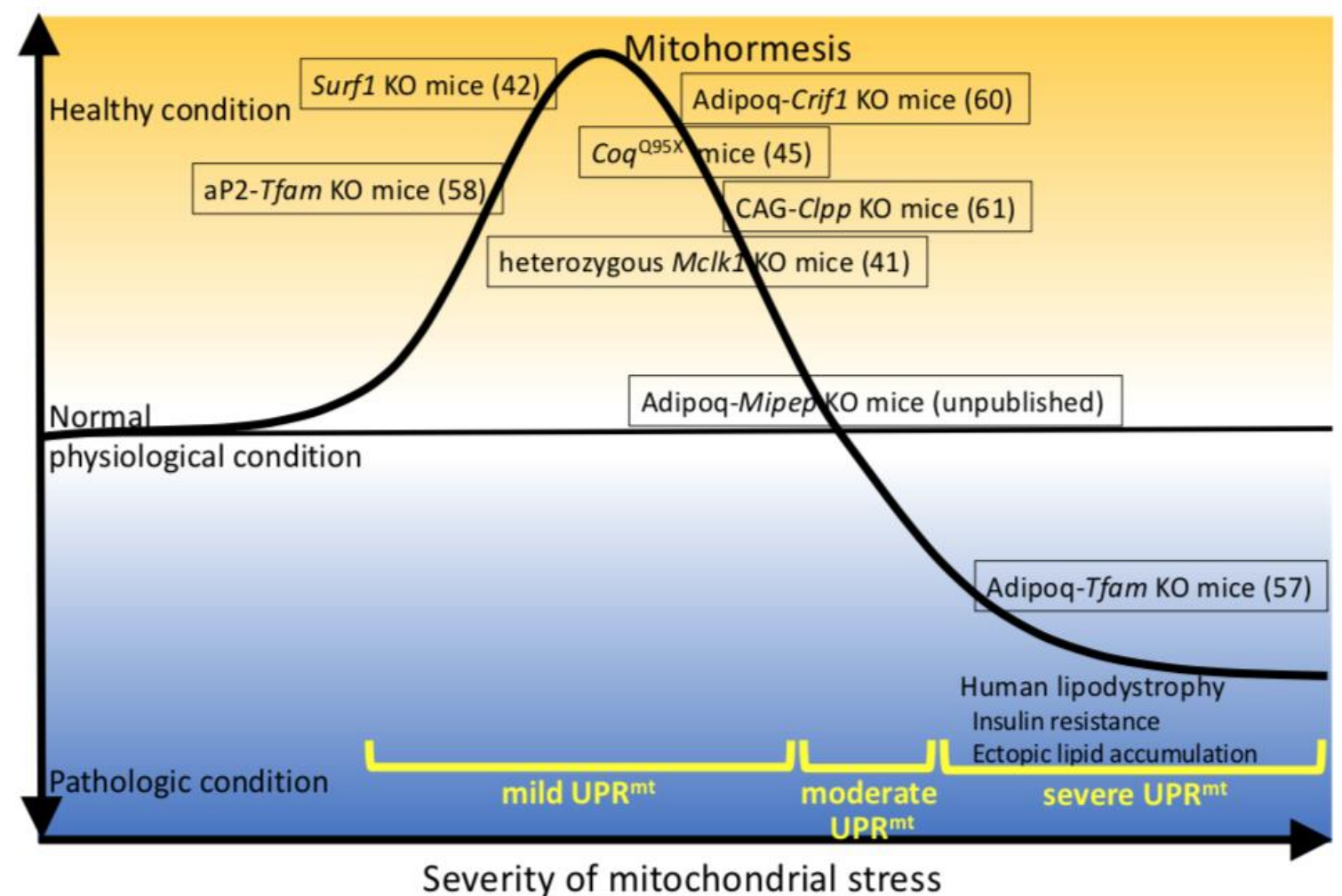

Figure 1. Proposed mechanism of interaction between the severity of mitochondrial stress and healthy conditions in mice based on findings derived from genetically modified mice, which develop lipoatrophy due to defective proteins involved in mitochondrial function. Numbers in parentheses indicate references.

Finally, to further understand the pathology and/or beneficial actions of UPR ${ }^{\mathrm{mt}}$ in lipoatrophic animal models, it is important to evaluate the severity of glucose tolerance and the degree of adipocyte differentiation by measuring plasma insulin, plasma adiponectin, and leptin levels. In addition, the importance of measuring plasma GDF15 and FGF21 levels as biomarkers of UPR ${ }^{\mathrm{mt}}$ should be highlighted.

Author Contributions: M.K. conceived of and wrote the manuscript; Y.N. edited the manuscript, Table and Figure; R.T. edited the manuscript; Y.H. conceived of, edited, and revised the manuscript. All authors have read and agreed to the published version of the manuscript.

Funding: This work was supported by Grant-in-Aid for Young Scientists (20K19686) and Grants-in-Aid for Scientific Research (B) (No. 20H04130) from the Japan Society for the Promotion of Science.

Institutional Review Board Statement: Not applicable.

Informed Consent Statement: Not applicable.

Data Availability Statement: Not applicable.

Acknowledgments: We thank J. Ludovic Croxford from Edanz Group (https: / / en-author-services. edanz.com/ac (accesed on 8 March 2021)) for editing a draft of this manuscript.

Conflicts of Interest: The authors declare no conflict of interest. 


\section{References}

1. Shpilka, T.; Haynes, C.M. The mitochondrial UPR: Mechanisms, physiological functions and implications in ageing. Nat. Rev. Mol. Cell Biol. 2018, 19, 109-120. [CrossRef]

2. Yi, H.-S.; Chang, J.Y.; Shong, M. The mitochondrial unfolded protein response and mitohormesis: A perspective on metabolic diseases. J. Mol. Endocrinol. 2018, 61, R91-R105. [CrossRef]

3. Quirós, P.M.; Langer, T.; López-Otín, C. New roles for mitochondrial proteases in health, ageing and disease. Nat. Rev. Mol. Cell Biol. 2015, 16, 345-359. [CrossRef] [PubMed]

4. Ouchi, N.; Parker, J.L.; Lugus, J.J.; Walsh, K. Adipokines in inflammation and metabolic disease. Nat. Rev. Immunol. 2011, 11, 85-97. [CrossRef]

5. Aguiar-Oliveira, M.H.; Bartke, A. Growth Hormone Deficiency: Health and Longevity. Endocr. Rev. 2019, 40, 575-601. [CrossRef] [PubMed]

6. Accili, D.; Drago, J.; Lee, E.J.; Johnson, M.D.; Cool, M.H.; Salvatore, P.; Asico, L.D.; José, P.A.; Taylor, S.I.; Westphal, H. Early neonatal death in mice homozygous for a null allele of the insulin receptor gene. Nat. Genet. 1996, 12, 106-109. [CrossRef] [PubMed]

7. Ueki, K.; Okada, T.; Hu, J.; Liew, C.W.; Assmann, A.; Dahlgren, G.M.; Peters, J.L.; Shackman, J.G.; Zhang, M.; Artner, I.; et al. Total insulin and IGF-I resistance in pancreatic beta cells causes overt diabetes. Nat. Genet. 2006, 38, 583-588. [CrossRef]

8. Laustsen, P.G.; Russell, S.J.; Cui, L.; Entingh-Pearsall, A.; Holzenberger, M.; Liao, R.; Kahn, C.R. Essential role of insulin and insulin-like growth factor 1 receptor signaling in cardiac development and function. Mol. Cell Biol. 2007, 27, 1649-1664. [CrossRef]

9. Michael, M.D.; Kulkarni, R.N.; Postic, C.; Previs, S.F.; Shulman, G.I.; Magnuson, M.A.; Kahn, C.R. Loss of insulin signaling in hepatocytes leads to severe insulin resistance and progressive hepatic dysfunction. Mol. Cell 2000, 6, 87-97. [CrossRef]

10. Blüher, M.; Kahn, B.B.; Kahn, C.R. Extended longevity in mice lacking the insulin receptor in adipose tissue. Science 2003, 299, 572-574. [CrossRef]

11. Otabe, S.; Yuan, X.; Fukutani, T.; Wada, N.; Hashinaga, T.; Nakayama, H.; Hirota, N.; Kojima, M.; Yamada, K. Overexpression of human adiponectin in transgenic mice results in suppression of fat accumulation and prevention of premature death by high-calorie diet. Am. J. Physiol. Endocrinol. Metab. 2007, 293, E210-E218. [CrossRef]

12. Chen, S.S.; Chen, J.F.; Johnson, P.F.; Muppala, V.; Lee, Y.H. C/EBP $\beta$, when expressed from the C/ebp $\alpha$ gene locus, can functionally replace $\mathrm{C} / \mathrm{EBP} \alpha$ in liver but not in adipose tissue. Mol. Cell Biol. 2000, 20, 7292-7299. [CrossRef]

13. Chiu, C.H.; Lin, W.D.; Huang, S.Y.; Lee, Y.H. Effect of a C/EBP gene replacement on mitochondrial biogenesis in fat cells. Genes Dev. 2004, 18, 1970-1975. [CrossRef]

14. Argmann, C.; Dobrin, R.; Heikkinen, S.; Auburtin, A.; Pouilly, L.; Cock, T.A.; Koutnikova, H.; Zhu, J.; Schadt, E.E.; Auwerx, J. Ppargamma2 is a key driver of longevity in the mouse. PLoS Genet. 2009, 5, 1000752. [CrossRef]

15. Fujii, N.; Narita, T.; Okita, N.; Kobayashi, M.; Furuta, Y.; Chujo, Y.; Sakai, M.; Yamada, A.; Takeda, K.; Konishi, T.; et al. Sterol regulatory element-binding protein-1c orchestrates metabolic remodeling of white adipose tissue by caloric restriction. Aging Cell 2017, 16, 508-517. [CrossRef]

16. Roufayel, R.; Kadry, S. Molecular Chaperone HSP70 and key regulators of apoptosis-A review. Curr. Mol. Med. 2019, 19, 315-325. [CrossRef] [PubMed]

17. Böttinger, L.; Oeljeklaus, S.; Guiard, B.; Rospert, S.; Warscheid, B.; Becker, T. Mitochondrial heat shock protein (Hsp) 70 and Hsp10 cooperate in the formation of Hsp60 complexes. J. Biol. Chem. 2015, 290, 11611-11622. [CrossRef]

18. D'Silva, P.; Liu, Q.; Walter, W.; Craig, E.A. Regulated interactions of mtHsp70 with Tim44 at the translocon in the mitochondrial inner membrane. Nat. Struct. Mol. Biol. 2004, 11, 1084-1091. [CrossRef]

19. Konovalova, S.; Liu, X.; Manjunath, P.; Baral, S.; Neupane, N.; Hilander, T.; Yang, Y.; Balboa, D.; Terzioglu, M.; Euro, L.; et al. Redox regulation of GRPEL2 nucleotide exchange factor for mitochondrial HSP70 chaperone. Redox Biol. 2018, 19 , 37-45. [CrossRef]

20. Ghosh, J.C.; Dohi, T.; Kang, B.H.; Altieri, D.C. Hsp60 regulation of tumor cell apoptosis. J. Biol. Chem. 2008, 283, 5188-5194. [CrossRef] [PubMed]

21. Ngo, J.K.; Pomatto, L.C.D.; Bota, D.A.; Koop, A.L.; Davies, K.J.A. Impairment of lon-induced protection against the accumulation of oxidized proteins in senescent wi-38 fibroblasts. J. Gerontol. Ser. A Biol. Sci. Med. Sci. 2011, 66, 1178-1185. [CrossRef] [PubMed]

22. Gatsogiannis, C.; Balogh, D.; Merino, F.; Sieber, S.A.; Raunser, S. Cryo-EM structure of the ClpXP protein degradation machinery. Nat. Struct. Mol. Biol. 2019, 26, 946-954. [CrossRef]

23. Restelli, L.M.; Oettinghaus, B.; Halliday, M.; Agca, C.; Licci, M.; Sironi, L.; Savoia, C.; Hench, J.; Tolnay, M.; Neutzner, A.; et al. Neuronal mitochondrial dysfunction activates the integrated stress response to induce fibroblast growth factor 21. Cell Rep. 2018, 24, 1407-1414. [CrossRef] [PubMed]

24. Fujita, Y.; Taniguchi, Y.; Shinkai, S.; Tanaka, M.; Ito, M. Secreted growth differentiation factor 15 as a potential biomarker for mitochondrial dysfunctions in aging and age-related disorders. Geriatr. Gerontol. Int. 2016, 16, 17-29. [CrossRef]

25. Koga, Y.; Povalko, N.; Inoue, E.; Nashiki, K.; Tanaka, M. Biomarkers and clinical rating scales for sodium pyruvate therapy in patients with mitochondrial disease. Mitochondrion 2019, 48, 11-15. [CrossRef]

26. Tsai, V.W.W.; Husaini, Y.; Sainsbury, A.; Brown, D.A.; Breit, S.N. The MIC-1/GDF15-GFRAL pathway in energy homeostasis: Implications for obesity, cachexia, and other associated diseases. Cell Metab. 2018, 28, 353-368. [CrossRef] [PubMed] 
27. Bootcov, M.R.; Bauskin, A.R.; Valenzuela, S.M.; Moore, A.G.; Bansal, M.; He, X.Y.; Zhang, H.P.; Donnellan, M.; Mahler, S.; Pryor, K.; et al. MIC-1, a novel macrophage inhibitory cytokine, is a divergent member of the TGF-beta superfamily. Proc. Natl. Acad. Sci. USA 1997, 94, 11514-11519. [CrossRef] [PubMed]

28. Böttner, M.; Suter-Crazzolara, C.; Schober, A.; Unsicker, K. Expression of a novel member of the TGF-beta superfamily, growth/differentiation factor-15/macrophage-inhibiting cytokine-1 (GDF-15/MIC-1) in adult rat tissues. Cell Tissue Res. 1999, 297, 103-110. [CrossRef]

29. Ding, Q.; Mracek, T.; Gonzalez-Muniesa, P.; Kos, K.; Wilding, J.; Trayhurn, P.; Bing, C. Identification of macrophage inhibitory cytokine-1 in adipose tissue and its secretion as an adipokine by human adipocytes. Endocrinology 2009, 150, 1688-1696. [CrossRef]

30. Chung, H.K.; Ryu, D.; Kim, K.S.; Chang, J.Y.; Kim, Y.K.; Yi, H.S.; Kang, S.G.; Choi, M.J.; Lee, S.E.; Jung, S.B.; et al. Growth differentiation factor 15 is a myomitokine governing systemic energy homeostasis. J. Cell Biol. 2017, 216, 149-165. [CrossRef] [PubMed]

31. Chung, H.K.; Kim, J.T.; Kim, H.W.; Kwon, M.; Kim, S.Y.; Shong, M.; Kim, K.S.; Yi, H.S. GDF15 deficiency exacerbates chronic alcohol- and carbon tetrachloride-induced liver injury. Sci. Rep. 2017, 7, 17238. [CrossRef] [PubMed]

32. Patel, S.; Alvarez-Guaita, A.; Melvin, A.; Rimmington, D.; Dattilo, A.; Miedzybrodzka, E.L.; Cimino, I.; Maurin, A.C.; Roberts, G.P.; Meek, C.L.; et al. GDF15 provides an endocrine signal of nutritional stress in mice and humans. Cell Metab. 2019, 29, 707-718. [CrossRef] [PubMed]

33. Hsu, J.Y.; Crawley, S.; Chen, M.; Ayupova, D.A.; Lindhout, D.A.; Higbee, J.; Kutach, A.; Joo, W.; Gao, Z.; Fu, D.; et al. Nonhomeostatic body weight regulation through a brainstem-restricted receptor for GDF15. Nature 2017, 550, 255-259. [CrossRef] [PubMed]

34. Nishimura, T.; Nakatake, Y.; Konishi, M.; Itoh, N. Identification of a novel FGF, FGF-21, preferentially expressed in the liver. Biochim. Biophys. Acta 2000, 1492, 203-206. [CrossRef]

35. Kharitonenkov, A.; Shiyanova, T.L.; Koester, A.; Ford, A.M.; Micanovic, R.; Galbreath, E.J.; Sandusky, G.E.; Hammond, L.J.; Moyers, J.S.; Owens, R.A.; et al. FGF-21 as a novel metabolic regulator. J. Clin. Invest. 2005, 115, 1627-1635. [CrossRef]

36. Kurosu, H.; Choi, M.; Ogawa, Y.; Dickson, A.S.; Goetz, R.; Eliseenkova, A.V.; Mohammadi, M.; Rosenblatt, K.P.; Kliewer, S.A.; Kuro-o, M. Tissue-specific expression of betaKlotho and fibroblast growth factor (FGF) receptor isoforms determines metabolic activity of FGF19 and FGF21. J. Biol. Chem. 2007, 282, 26687-26695. [CrossRef]

37. Ding, X.; Boney-Montoya, J.; Owen, B.M.; Bookout, A.L.; Coate, K.C.; Mangelsdorf, D.J.; Kliewer, S.A. betaKlotho is required for fibroblast growth factor 21 effects on growth and metabolism. Cell Metab. 2012, 16, 387-393. [CrossRef]

38. Fon Tacer, K.; Bookout, A.L.; Ding, X.; Kurosu, H.; John, G.B.; Wang, L.; Goetz, R.; Mohammadi, M.; Kuro-o, M.; Mangelsdorf, D.J.; et al. Research resource: Comprehensive expression atlas of the fibroblast growth factor system in adult mouse. Mol. Endocrinol. 2010, 24, 2050-2064. [CrossRef]

39. Fujii, N.; Uta, S.; Kobayashi, M.; Sato, T.; Okita, N.; Higami, Y. Impact of aging and caloric restriction on fibroblast growth factor 21 signaling in rat white adipose tissue. Exp. Gerontol. 2019, 118, 55-64. [CrossRef]

40. Bárcena, C.; Mayoral, P.; Quirós, P.M. Mitohormesis, an antiaging paradigm. Int. Rev. Cell Mol. Biol. 2018, 340, 35-77. [CrossRef]

41. Liu, X.; Jiang, N.; Hughes, B.; Bigras, E.; Shoubridge, E.; Hekimi, S. Evolutionary conservation of the clk-1-dependent mechanism of longevity: Loss of mclk1 increases cellular fitness and lifespan in mice. Genes Dev. 2005, 19, 2424-2434. [CrossRef]

42. Dell'agnello, C.; Leo, S.; Agostino, A.; Szabadkai, G.; Tiveron, C.; Zulian, A.; Prelle, A.; Roubertoux, P.; Rizzuto, R.; Zeviani, M. Increased longevity and refractoriness to $\mathrm{Ca}(2+)$-dependent neurodegeneration in Surf1 knockout mice. Hum. Mol. Genet. 2007, 16, 431-444. [CrossRef]

43. Lapointe, J.; Hekimi, S. Early mitochondrial dysfunction in long-lived Mclk1+/- mice. J. Biol. Chem. 2008, 283, $26217-26227$. [CrossRef] [PubMed]

44. Wang, D.; Wang, Y.; Argyriou, C.; Carrière, A.; Malo, D.; Hekimi, S. An enhanced immune response of Mclk $1^{+/-}$mutant mice is associated with partial protection from fibrosis, cancer and the development of biomarkers of aging. PLoS ONE 2012, 7, 49606. [CrossRef]

45. Luna-Sánchez, M.; Díaz-Casado, E.; Barca, E.; Tejada, M.Á.; Montilla-García, Á.; Cobos, E.J.; Escames, G.; Acuña-Castroviejo, D.; Quinzii, C.M.; López, L.C. The clinical heterogeneity of coenzyme Q10 deficiency results from genotypic differences in the Coq9 gene. EMBO Mol. Med. 2015, 7, 670-687. [CrossRef] [PubMed]

46. Rodríguez-Hidalgo, M.; Luna-Sánchez, M.; Hidalgo-Gutiérrez, A.; Barriocanal-Casado, E.; Mascaraque, C.; Acuña-Castroviejo, D.; Rivera, M.; Escames, G.; López, L.C. Reduction in the levels of CoQ biosynthetic proteins is related to an increase in lifespan without evidence of hepatic mitohormesis. Sci. Rep. 2018, 8, 14013. [CrossRef]

47. Monaghan, R.M.; Barnes, R.G.; Fisher, K.; Andreou, T.; Rooney, N.; Poulin, G.B.; Whitmarsh, A.J. A nuclear role for the respiratory enzyme CLK-1 in regulating mitochondrial stress responses and longevity. Nat. Cell Biol. 2015, 17, 782-792. [CrossRef] [PubMed]

48. Deepa, S.S.; Pulliam, D.; Hill, S.; Shi, Y.; Walsh, M.E.; Salmon, A.; Sloane, L.; Zhang, N.; Zeviani, M.; Viscomi, C.; et al. Improved insulin sensitivity associated with reduced mitochondrial complex IV assembly and activity. FASEB J. 2013, 27, 1371-1380. [CrossRef]

49. Pulliam, D.A.; Deepa, S.S.; Liu, Y.; Hill, S.; Lin, A.L.; Bhattacharya, A.; Shi, Y.; Sloane, L.; Viscomi, C.; Zeviani, M.; et al. Complex IV-deficient Surf1 (-/-) mice initiate mitochondrial stress responses. Biochem. J. 2014, 462, 359-371. [CrossRef] [PubMed] 
50. Deepa, S.S.; Pharaoh, G.; Kinter, M.; Diaz, V.; Fok, W.C.; Riddle, K.; Pulliam, D.; Hill, S.; Fischer, K.E.; Soto, V.; et al. Lifelong reduction in complex IV induces tissue-specific metabolic effects but does not reduce lifespan or healthspan in mice. Aging Cell 2018, 17, 12769. [CrossRef] [PubMed]

51. Zhang, Y.; Xie, Y.; Berglund, E.D.; Coate, K.C.; He, T.T.; Katafuchi, T.; Xiao, G.; Potthoff, M.J.; Wei, W.; Wan, Y.; et al. The starvation hormone, fibroblast growth factor-21, extends lifespan in mice. Elife 2012, 1, 00065. [CrossRef] [PubMed]

52. Wang, X.; Chrysovergis, K.; Kosak, J.; Kissling, G.; Streicker, M.; Moser, G.; Li, R.; Eling, T.E. HNAG-1 increases lifespan by regulating energy metabolism and insulin/IGF-1/mTOR signaling. Aging (Albany NY) 2014, 6, 690-704. [CrossRef] [PubMed]

53. Chrysovergis, K.; Wang, X.; Kosak, J.; Lee, S.H.; Kim, J.S.; Foley, J.F.; Travlos, G.; Singh, S.; Baek, S.J.; Eling, T.E. NAG-1/GDF-15 prevents obesity by increasing thermogenesis, lipolysis and oxidative metabolism. Int. J. Obes. (Lond.) 2014, 38, 1555-1564. [CrossRef]

54. Luan, H.H.; Wang, A.; Hilliard, B.K.; Carvalho, F.; Rosen, C.E.; Ahasic, A.M.; Herzog, E.L.; Kang, I.; Pisani, M.A.; Yu, S.; et al. GDF15 is an inflammation-induced central mediator of tissue tolerance. Cell 2019, 178, 1231-1244.e11. [CrossRef]

55. Jung, S.B.; Choi, M.J.; Ryu, D.; Yi, H.S.; Lee, S.E.; Chang, J.Y.; Chung, H.K.; Kim, Y.K.; Kang, S.G.; Lee, J.H.; et al. Reduced oxidative capacity in macrophages results in systemic insulin resistance. Nat. Commun. 2018, 9, 1551. [CrossRef]

56. Gaspari, M.; Larsson, N.G.; Gustafsson, C.M. The transcription machinery in mammalian mitochondria. Biochim. Biophys. Acta 2004, 1659, 148-152. [CrossRef] [PubMed]

57. Vernochet, C.; Damilano, F.; Mourier, A.; Bezy, O.; Mori, M.A.; Smyth, G.; Rosenzweig, A.; Larsson, N.G.; Kahn, C.R. Adipose tissue mitochondrial dysfunction triggers a lipodystrophic syndrome with insulin resistance, hepatosteatosis, and cardiovascular complications. FASEB J. 2014, 28, 4408-4419. [CrossRef]

58. Vernochet, C.; Mourier, A.; Bezy, O.; Macotela, Y.; Boucher, J.; Rardin, M.J.; An, D.; Lee, K.Y.; Ilkayeva, O.R.; Zingaretti, C.M.; et al. Adipose-specific deletion of TFAM increases mitochondrial oxidation and protects mice against obesity and insulin resistance. Cell Metab. 2012, 16, 765-776. [CrossRef] [PubMed]

59. Kim, S.J.; Kwon, M.C.; Ryu, M.J.; Chung, H.K.; Tadi, S.; Kim, Y.K.; Kim, J.M.; Lee, S.H.; Park, J.H.; Kweon, G.R.; et al. CRIF1 is essential for the synthesis and insertion of oxidative phosphorylation polypeptides in the mammalian mitochondrial membrane. Cell Metab. 2012, 16, 274-283. [CrossRef] [PubMed]

60. Choi, M.J.; Jung, S.B.; Lee, S.E.; Kang, S.G.; Lee, J.H.; Ryu, M.J.; Chung, H.K.; Chang, J.Y.; Kim, Y.K.; Hong, H.J.; et al. An adipocyte-specific defect in oxidative phosphorylation increases systemic energy expenditure and protects against diet-induced obesity in mouse models. Diabetologia 2020, 63, 837-852. [CrossRef] [PubMed]

61. Bhaskaran, S.; Pharaoh, G.; Ranjit, R.; Murphy, A.; Matsuzaki, S.; Nair, B.C.; Forbes, B.; Gispert, S.; Auburger, G.; Humphries, K.M.; et al. Loss of mitochondrial protease ClpP protects mice from diet-induced obesity and insulin resistance. EMBO Rep. 2018, 19, 45009. [CrossRef]

62. Kobayashi, M.; Takeda, K.; Narita, T.; Nagai, K.; Okita, N.; Sudo, Y.; Miura, Y.; Tsumoto, H.; Nakagawa, Y.; Shimano, H.; et al. Mitochondrial intermediate peptidase is a novel regulator of sirtuin-3 activation by caloric restriction. FEBS Lett. 2017, 591, 4067-4073. [CrossRef]

63. Mann, J.P.; Savage, D.B. What lipodystrophies teach us about the metabolic syndrome. J. Clin. Investig. 2019, $129,4009-4021$. [CrossRef] [PubMed]

64. He, W.; Barak, Y.; Hevener, A.; Olson, P.; Liao, D.; Le, J.; Nelson, M.; Ong, E.; Olefsky, J.M.; Evans, R.M. Adipose-specific peroxisome proliferator-activated receptor gamma knockout causes insulin resistance in fat and liver but not in muscle. Proc. Natl. Acad. Sci. USA 2003, 100, 15712-15717. [CrossRef]

65. Wang, F.; Mullican, S.E.; DiSpirito, J.R.; Peed, L.C.; Lazar, M.A. Lipoatrophy and severe metabolic disturbance in mice with fat-specific deletion of PPAR . Proc. Natl. Acad. Sci. USA 2013, 110, 18656-18661. [CrossRef] [PubMed]

66. Wang, Z.V.; Deng, Y.; Wang, Q.A.; Sun, K.; Scherer, P.E. Identification and characterization of a promoter cassette conferring adipocyte-specific gene expression. Endocrinology 2010, 151, 2933-2939. [CrossRef]

67. Mullican, S.E.; Tomaru, T.; Gaddi, C.A.; Peed, L.C.; Sundaram, A.; Lazar, M.A. A novel adipose-specific gene deletion model demonstrates potential pitfalls of existing methods. Mol. Endocrinol. 2013, 27, 127-134. [CrossRef] [PubMed]

68. Molenaars, M.; Janssens, G.E.; Williams, E.G.; Jongejan, A.; Lan, J.; Rabot, S.; Joly, F.; Moerland, P.D.; Schomakers, B.V.; Lezzerini, M.; et al. A conserved mito-cytosolic translational balance links two longevity pathways. Cell Metab. 2020, 31, 549-563. [CrossRef] [PubMed] 